\title{
The Fleury Playbook: Liturgical Drama and its Production in Saint-Benoît-sur-Loire
}

\author{
Amálie Bulandrová
}

\begin{abstract}
Abstrakt
Předkládaná studie se zabývá funkcí vizuálních elementů uvnitř sakrálních středověkých budov během konání liturgického divadla. V první části autorka vymezuje druh této veřejné události, upozorňuje na jeho těsnou provázanost se samotnou liturgií a na její divadelní rozměr. Činí tak prostřednictvím různých historických textů, jež dokazují, že tendence přemýšlet o liturgii jako o performanci svého druhu existují již od 9. století. V návaznosti na tuto myšlenku pak pojímá interiéry sakrálních budov jako scénografická řešení liturgického divadla, tj. místa jeho konání. Př́kladem je benediktinské opatství ve Fleury, v jehož klášterní knihovně byla nalezena sbírka deseti liturgických her z 12. století (tzv. Fleury Playbook). Zvážíme-li dobové inscenování těchto her v místním kostele Svatého Benedikta, je nasnadě jej v tomto kontextu chápat právě jako scénografické prostředí. Uvedený příklad proto tvoří jádro této studie a detailněji je rozebrán v její druhé části.
\end{abstract}

\section{Klíčová slova}

liturgické divadlo; liturgie; Fleury Playbook; Saint-Benoît-sur-Loire; Opatství Fleury; poutnictví; rituální prostor; scénografie

\begin{abstract}
Present study comprises the function of visual elements of medieval sacred buildings in liturgical theatre productions. In the first part, the author defines the theatrical genre, outlining its connection to liturgy proper which itself has a striking theatrical quality. Based on a number of period texts, the author proves the tendencies to consider liturgy a kind of theatrical performance existed as early as the 9th century. As a consequence, the interiors of sacred buildings are considered stage designs for performances of liturgical theatre, and analysed as such, e. g. Benedictine abbey St. Fleury (France), the library of which hosts a manuscript of ten liturgical plays from 12th century, so-called Fleury Playbook. The plausible staging of these plays in the monastic church of St. Benedict is yet another reason to regard the church as a scenographic environment, as is argued in detail in the second part of the paper.
\end{abstract}

\section{Keywords}

liturgical theatre; liturgy; Fleury Plabook; Saint-Benoît-sur-Loire; Fleury Abbey; pilgrimage; ritual space; stage design; scenography 
This paper reports on the international research project called Migrating Art Historians, which was initiated and led by Assoc. Prof. Ivan Foletti, MA, Docteur es Lettres (Department of the History of Art, Faculty of Arts, Masaryk University) during spring 2017. Within this project, a group of 12 scholars went walking through France for 4 months and examined the connections between the medieval pilgrimage and the sacral medieval art. The project aimed at experiencing the art through the movement of one's own body and consequently putting those experiences into the context of historical knowledge of the given area and the period of the $11^{\text {th }}-13^{\text {th }}$ century. One of the important medieval pilgrimage centers, as well as one of the stops during the project, was the Benedictine abbey called Fleury. The research group stayed there for several days and together with the scholars from France analyzed on the local church of SaintBenoîtand its arts. With regard to this place, it holds a significant finding which must be considered - the collection of 10 liturgical plays from the $12^{\text {th }}$ century called the Fleury Playbook. The collection was found in the cloister library, and it therefore indicates the possible staging of liturgical plays in this church. The results of this stay were presented at the conference entitled Migrating Art Historians Workshop II: Monumentality Performance and Manuscripts accessible through the website of the project. The present study is, therefore, rather an outline of this topic which will be analyzed in more detail in the forthcoming book Migrating Art Historians that is planned to be published by Ivan Foletti and the Centre for Early Medieval Studies in spring 2018.

This study deals with the function of visual elements inside the sacral space during production of liturgical drama. It also relates to the mediation of the images in the ritual space and methods through which the mediation was achieved: in other words, what made the images accessible to the public. The answer is broad, and one solution is evidently through the liturgy: through liturgical context, which guides their interpretation. Connected with the liturgy are also various forms of exegesis like commentaries and readings.

Another way of transmitting the images to the public is by making them alive: not only through spoken words but also through mimetic representation. Narrowly connected with this explication via "reviving", or perhaps an extension of it, is the category of the so-called "liturgical-drama", the phenomenon which is not in use anymore though the memories and traces of it are still possible to find in the field of the sacral medieval art. The church architecture and its decoration could be, for instance, also understood as a scenography for a particular liturgical play. The above-mentioned Benedictine Abbey at Fleury with its famous Fleury Playbook will be further discussed as a key example of such use.

Even though we do not have any specific idea about how the original performances of liturgical drama looked like, we do have at our disposal the texts and the probable staging area (the actual space as well as the decorations, like the narrative columns for instance). These elements could be understood as a scenography, as a visual setting for specific dramatic liturgical productions. As Elizabeth C. Parker in her essay Architecture as Liturgical Setting pointed out, it was the church architecture that determined the shape of the liturgy, or the more so, "[the] church has been shaped by it, it is nevertheless safe 
to say that from early Christian times the architectural environment of a church has been used to create a dramatic setting for liturgical ritual which, in varying forms, enhance the sense of divine presence in the midst of its performance" (PARKER 2001: 273).

The question is, therefore, focused on what can be understood from those settings in relation to the staging of dramatic texts: how could wall-paintings, column decorations and sculpted elements on the tympanums work together with the narration of the drama? Were those visual components considered when the productions of the plays were being prepared? In which way was the liturgical drama staged / was made to happen here, and how it interacted with the images and space? The answers to those questions will always incite speculation; nevertheless, it is worth putting them; to go through the already discovered data and consider them in new horizons and connections, such as the church decoration for example.

\section{The dramatic aspects of the liturgy}

To understand how liturgical plays could help experience the space, or how the mimetic representation of historical characters could help lay people approach the story of Salvation, it is first necessary to get an insight about the dramatic aspect of liturgy.

The scholarly research concerning the connection between liturgy and drama began with E. K. Chambers's Mediaeval Stage (1903) and was followed by his most important "successor" Karl Young and his The Drama of the Medieval Church (1933). However, with time, their works became the subject of critique, which begun with O. C. Hardison and continued by a number of scholars during the years-to-come. The point which Hardison re-considers is based on the positivist theatre historiography claiming that the stage area of medieval drama gradually moved from the church to the church portal, from the church portal to the plaza in front of the church, and from there to movable cars, changing the language of the production from Latin to vernacular in the process (HARDISON 1965: 1-35). However, as several scholars have proved, this is far from sufficient and the "Darwinian" principle of the model is erroneous. ${ }^{1}$

Hardison suggests that in the $9^{\text {th }}$ century a clear boundary between religious ritual (the services of the Church) and drama did not exist: "Religious ritual was the drama of the early Middle Ages and had been ever since the decline of the classical theatre" (HARDISON 1965: VIII). As the most valuable source of his research Hardison quotes the Liber officialis by Amalarius of Metz (died around 850), bishop and prominent figure at the courts of Charlemagne and Louis the Pious. Amalarius' influence was largely expanded through the liturgical commentaries during the later Middle Ages. Hardison in his study Christian Rite and Christian Drama in the Middle Ages explains that "[t]he

1 As Hardison demonstrates in his essay on earliest vernacular dramas, the Mystère d'Adam and the Sainte Résurrection, both from the $12^{\text {th }}$ century, there existed a vernacular tradition in the $12^{\text {th }}$ century and this tradition was already independent of the Latin drama from which it is usually said to be derived: "The evidence indicates that they are consciously composed works, written for a theatre that already possessed definite tradition of staging and acting, and conceived from the beginning as representation" (HARDISON 1965: IX). 
Liber Officialis shows, first, that the Mass was consciously interpreted as drama during the ninth century, and second, that representational ceremonies were common in the Roman liturgy long before the earliest manuscript of the Quem quaritis" (HARDISON 1965: VIII), which is traditionally considered the beginning of the medieval drama.

Hardison demonstrates this attitude to the idea of allegorical interpretation of the Mass, which relates to the Dialogues of Gregory the Great (540-604) whose successors were accustomed to regard Scripture "as a fusion of a literal (i.e., "visible") meaning with three kinds of symbolic meaning: allegorical, topological, and anagogical. By the ninth century this system of analysis was being used to explain the invisible realities of the Mass" (HARDISON 1965: 36). The Liber officialis of Amalarius then serves the major source for Hardison who interprets it as an answer for a "strongly felt need for an interpretation of the Mass which emphasized its immediate, as against its historical, significance" (HARDISON 1965: 39).

Elizabeth C. Parker is another scholar to analyze the allegorical interpretation of the liturgy, namely Roman stational one. For her, the interesting part is the connection between the architectural and liturgical development of the Carolingian period when Amalarius's assignment of roles in the congregation was highly influential (PARKER 2001: 290-301). She also focuses on the assignment for the choir and the hierarchy of the clergy "who participate in the rememorative drama of the life, ministry, crucifixion, and resurrection of Christ that unfolds in the Mass, enriched by the chants and hymns that accompanied it, served as a model for later liturgies to complement the rubrics and tone of the structure of Mass established by Gregory the Great", explains Parker (PARKER 2001: 291).

The author also gives a general overview of how the "Amalarian vision of the Mass" was constructed and puts his allegorical interpretations of the gestures and movements of the celebrant and his assistants at different moments of the Mass into the context of the dramatic embellishments of the $10^{\text {th }}$ century. ${ }^{2}$ Those embellishments were largely attached to the Easter liturgy during the $10^{\text {th }}$ century monastic reform movement, most fully recorded in the Winchester document called the Regularis Concordia dating back to 973 AD (PARKER 2001: 291-292).

To dramatize the reality of the events of the Passion, [...], the document provides an extraliturgical option of solemn procession to a separate altar for the burial of the cross in a "sepulchre", [...] At Easter Sunday Matins, the sepulchre without the cross was the destination of three monks dressed as the Marys, who were told by the monk portraying the angel that the Christ they seek is not there but has risen, and they are shown the empty tomb. (PARKER 2001: 291-292)

2 "The full length of the basilican space provides a setting for moving through sacred time: at the antiphonal Introit hymn, the chorus (representing Old Testament prophets) announces the entrance of the bishop (representing the advent of Christ) at the head of a solemn procession (representing Christ's Entry into Jerusalem), acclaimed by the congregation (representing Jewish people). The bishop's seating on the elevated chair on the synthronon in the center of the apse - an area associated with the paradise - above and beyond the altar table where the eucharistic sacrifice takes place, represents Ascension of Christ." (PARKER 2001: 290-291) 
The action called Quem queritis, in its extended form also known as Visitatio Sepulchri, is considered to be the first of liturgical dramas frequently performed on major feast days from that time on throughout all the medieval era. The important aspect of these theatrical performances was, apart from others, the fact that lay people were not present at the crucial events of the history of Salvation. This could cause an emotional sadness (as described for example in Anselm's prayer) and the desire to re-enact them. As Parker concludes, this accentuation of the need for visual stimuli was "further satisfied not only by art and drama but also in the pomp and spectacle of ever more elaborate processionals, for Corpus Christi and other feast days in England and on the continent" (PARKER 2001: 310).

The analyzed Amalarian interpretations thus clearly testify close relationship between the allegorical interpretation of the liturgy and the history of drama. As Hardison proved, they present the Mass as a sophisticated drama where the roles assigned to the participants are strictly definite and where the plot "is nothing less than a 'renewal of the whole plan of redemption' through the re-creation of 'life, death, and resurrection' of Christ" (HARDISON 1965: 39).

Though much of Amalarius thought was censured during his lifetime, his "allegorical" and dramatic method of liturgical exegesis dominated the popular sacramental teaching of the following centuries (MCCALL 2007: 2). As one example, let me present the expression of this idea from the Gemma animae, written in about 1100 by Honorius of Autun:

It is known that those who recited tragedies in theatres presented the actions of opponents by gestures before the people. In the same way our tragic author [i.e. the celebrant] represents by his gestures in the theatre of the Church before the Christian people the struggle of Christ and teaches to them the victory of His redemption. Thus when the celebrant [presbyter] says the Orate [fratres] he expresses Christ placed for us in agony, when he commanded His apostles to pray. By the silence of the Secreta he expresses Christ as a lamb without voice being led to the sacrifice. By the extension of his hands he represents the extension of Christ hanging on the Cross. By the chant of the Preface he expresses the cry of Christ hanging on the Cross. [...] (HARDISON 1965: 39-40)

This passage highlights the importance of liturgical allegory to the history of drama, which, according to Hardsion, is reinforced by Honorius' usage of the vocabulary of dramatic criticism. In this sense, the church is regarded as a theatre in which "[t]he drama enacted has a coherent plot based on conflict (duellum) between a champion and an antagonist. The plot has a rising action, culminating in the Passion and entombment. [...] Something like dramatic catharsis is expressed in the gaudium of the Postcommunion" (HARDISON 1965: 40).

Whatever else may be said about Honorius, the fact that he understood the Mass as a living dramatic form is evident for Hardison. Therefore, the scholar concludes "that the 'dramatic instinct' of European man did not 'die out' during the earlier Middle Ages, as historians of drama have asserted. Instead, it found expression in the central 
ceremony of Christian worship, the Mass" (HARDISON 1965: 41). Just as Elizabeth C. Parker, Hardison stresses the rememorative function of the Mass: as a rememorative drama, where the elements vary according to the interpreter; the Mass depicts the life, ministry, crucifixion, and resurrection of Christ. Thus, the rememorative allegory is always present (HARDISON 1965: 35-80).

Richard D. McCall in his Liturgy as Performance indicates that "such a dramatic analysis of the liturgy has not, however, been confined to the 'official' teachings of the church" (MCCALL 2007: 3), and explains that later medieval drama (for example the Passion and mystery cycles) has been often considered a "commentary" on the Liturgy of the Church, or its "expansion" in dramatic form. In the same vein, McCall (MCCALL 2007: 5) recapitulates that modern approaches to the history of medieval drama (as in Hardison [1965]) make the understanding of the Mass as dramatic enactment as their starting point. The author then gives an overview of those modern debates, which, according to him, are more oriented towards what exactly constitutes "drama" and how it is different from the "liturgy", rather than tries to answer the question whether there is a dramatic element to the liturgy. ${ }^{3}$ As McCall concludes, recent theories of semiotics and performance, "have opened an even broader horizon for looking at the nature of the act or constellation of acts that forms the basis not only of drama and liturgy but of social acts, political acts, and even reality itself as it is enacted moment by moment as once-occurrent Being-as-event"4 (MCCALL 2007: 3).

\section{The traces of the "performative-past"}

Whatever stood at the beginning of the development of liturgical drama, the fact is that we have a large number of more or less preserved and elaborated dramatic texts from the $10^{\text {th }}$ century on, which were obviously inseparable from the liturgy and therefore are now called "liturgical drama". In cases where those dramatic texts relate to a known provenance with actual medieval buildings, it is sometimes possible to match the texts and constructions together and try to analyze how the dramas might have been performed in these spaces. It is, nevertheless, quite a rare situation that an extant liturgical script can be related to a concrete space of its original staging. This is the case of the cathedral in Rouen, for example, where the renowned dramatic texts from $12^{\text {th }}$ to $14^{\text {th }}$ century were found and which - according to the stage directions in rubrics of the texts - were conceived to be performed there. ${ }^{5}$

3 "Is it the presence of costumes or impersonation or scripts or stage directions or an audience that separates a 'play' from a 'liturgy'? Or is it something else that 'frames' the action and tells us in one case, 'This is a play' and in another, 'This is a liturgy'?" (MCCALL 2007: 3)

4 Especially in the work of Mikhail Bakhtin, Roland Barthes, and Umberto Eco, deriving from the linguistic theories of Ferdinand de Saussure and Louis Hjelmslev.

5 "Rubrics of medieval drama are usually regarded one-sidedly as production (directorial) notes, and it is from this aspect - as more or less articulated set of instructions for production - that they are logically interpreted. [...] Sometimes rubrics are very scarce, unclear or ambiguous. They can be fragmentary, indecipherable and difficult to interpret, and in extreme cases they may be missing completely. Conversely, there 
A similar case is also the so-called Fleury Playbook, a collection of 10 liturgical dramas from the $12^{\text {th }}$ century, which is connected with the abbey of Saint-Benoit-sur-Loire. Despite the fact that this anthology was copied at Fleury in one hand in the third quarter of the $12^{\text {th }}$ century, there is no certainty that it originated in Fleury or that the plays were meant to be performed (only) there. ${ }^{6}$ Nevertheless, the fact that the manuscript was at least copied and housed in the cloister library indicates possible productions of its plays in that monastery, specifically in its church. In general, the Fleury Playbook reveals important concepts for the staging of the music-drama in the medieval church, which could be therefore understood as a potential scenography for its productions. ${ }^{7}$ On that account, this article aims at outlining the way in which the architectonic and decorative elements of the Saint-Benoît church could, together with other elements such as acting and music, create meanings of the perceived liturgical dramas.

\section{The Fleury Playbook}

The Fleury Playbook is one of the most extraordinary collections of medieval liturgical drama. It was found in MS. Orleans 201 - the $12^{\text {th }}$ century manuscript from the library of the Abbey of Saint-Benoît-sur-Loire at Fleury. ${ }^{8}$

The place of its discovery represents a famous and well-studied point of interest of many scholars: the abbey was founded as early as 651 and became famous especially for the relics of St. Benedict which were transferred there from Monte Cassino in the $8^{\text {th }}$ century. Later, after the Cluniac reformation, this monastery became a model monastic institution and during the $9^{\text {th }}$ to the $13^{\text {th }}$ century represented a respected center of culture, learning and arts.

The ten plays of the Fleury Playbook deal with a challenging variety of subjects. In the manuscript order, there can be found four St. Nicholas plays, an Officium Stellae (that is, a play of Herod, the Magi, and the shepherds), an Ordo Rachelis, a play depicting the Slaughter of Innocents and the lament of Rachel, the wife of Jacob, a Visitatio Sepulchri or Visit to the Sepulcher, a Peregrinus play, a Conversion of St. Paul and a Raising of Lazarus. ${ }^{9}$

are playscripts containing very detailed and extensive rubrics that almost resemble a production notebook. Because of the diversity and inconsistency of rubrics it is hardly possible to define general rules and uniform traits of their style and form." (VRŠECKÁ 2013: 1)

6 For further discussion of the issue see e.g., Dunbar H. Ogden The Staging of Drama in the Medieval Church (2002) and Fletcher Collins, Jr. The Home of the Fleury Playbook (1985).

7 See the introduction of this chapter.

8 The manuscript collection is a compilation of three separate manuscripts which were bound together probably in the $16^{\text {th }}$ century. The first part of the manuscript consists mostly of a series of homilies dedicated to the Virgin Mary. The second section, which represents the main interest of this study, is the collection of 10 liturgical plays. Finally, the third section of the manuscript is quite short and contains sequences to the Virgin and St. Laumer. Of these 3 sections, only the latter two have musical notation. Altogether, the manuscript is composed of 251 foils of a relatively small size $(63 / 4 \times 5 \%$ ) (FLANIGAN, CAMPBELL and DAVIDSON 1985).

9 As to the rubrical evidence revealing the location of performances of the respective plays, they can be divided in two categories: (1) the Visitatio Sepulchri, Peregrinus, Officium Stellae, and Ordo Rachelis contain direct references to their presentation in both choir and nave; and (2) the plays of St. Nicholas, St. Paul, and Lazarus do not mention any location at all. 
Unfortunately, no details of either architecture or furnishing of the acting space are given in the rubrics of any of the plays, but what can be reconstructed of the actual mise-en-scène fits the church of Saint-Benoît quite well (OGDEN 2002: 75). Likewise, all references in the rubrics concerning the physical aspects of the building correspond to the structure of the church, allowing for the hypothesis that the plays might have been recorded with regard to their stage performance in Fleury in particular or at least in different churches, one of them being the one in Fleury. This might be the reason why references to such specific items as particular altars are missing in the playscripts (OGDEN 2002: 75, 86).

The present study is limited to a thorough study of just one play of the whole corpus, the Officium Stellae, selected for its pilgrim aspect and the distinctive role of the "audience" in its production.

\section{Officium Stellae (Office of the Star)}

The Fleury version of Ordo Stellae represents the most developed form of this type of liturgical play found in France, actually consisting of three separate plotlines: the play of Herod, of the Magi, and of the Shepherds. I will first summarize the plot of the Office as it is related in the preserved script, and then outline the possible associations of the given dramatic situations with the interior and exterior of Saint-Benoit church. Since the dramatic texts have been translated and interpreted by many scholars and the author of this study is not the classical linguist to translate them again, this part of the article only recapitulates the already discovered facts. Consequently, the attempt is to put them into perhaps newly observed links connected with medieval pilgrimage art. The chosen reference sources are mostly the works of the American scholars Dunbar H. Ogden and David Bevington, and a British researcher Thomas P. Campbell, who, by close reading of the original Latin dramatic text and its rubrics, reconstructed the possible staging script of this play. ${ }^{10}$

\section{Plot}

The dramatic action of the Officium Stellae play is centered around the Magi who meet somewhere in the church and then, following the star (probably attached on some kind of mechanical device), seek for the newly born Christ child. During their journey, they are driven by soldiers to the Herod's court and asked to witness about the arrival of the Messiah. They are, however, released and let go safely shortly after. At the same time,

10 There was a symposium on the Fleury Playbook at the Fifteenth International Congress on Medieval Studies at Western Michigan Universtity in 1980 and as its academic output the collection of related essays and studies was published in 1985. Among others, Thomas P. Campbell ("Augustine's Concept of the Two Cities and the Fleury Playbook") and David Bevington ("The Staging of Twelfth-Century Liturgical Drama in the Fleury Playbook") published their studies there and the present article is largely based on their works (FLANIGAN, CAMPBELL and DAVIDSON 1985). 
somewhere else in the church, the simultaneous scene of the shepherds by the Manger is staged. ${ }^{11}$ In this scene, the shepherds announce the arrival of the Messiah and Christ Child is born. At the end of the play, the Magi manage to find (thanks to the star) the Manger and homage there to the newly-born Christ Child.

\section{Organization of the space}

From the described plot, it seems evident that the staging of the play requires three major stations: the meeting place of the Magi at the main altar, the court of Herod, and the Manger. ${ }^{12}$ Information specifying the design of these stations that can be reconstructed from the rubrics of this play are the following: Herod is probably seated on a throne since his young companions are noted as being seated too, and he is surrounded by quite an entourage, all of whom may have been positioned on some kind of raised platform; the location of the Christmas Manger in the first part of the Shepherds scene has been a subject of a good deal of speculation which finally led to the belief that it was set at the entrance to the church at the west end of the nave ${ }^{13}$ (OGDEN 2002: 78). Whether the Manger was covered with some kind of a curtain (as was often the case when staging labour in liturgical theatre) is not possible to tell from the rubrics. What is clear, however, is the presence of two midwives somewhere near the Manger showing the Christ Child to the crowd and an angel situated above them.

\section{Interpretation}

Having the given facts about the reconstructed staging-process in mind, the question is how they can help interpret the space of the (actual) church. How can the narrative help us better understand the architecture and decoration of the church which, as has already been mentioned, can be considered a scenography for the actual production of a piece of liturgical drama? I will try to answer this question with the help of the two above mentioned perspectives - the audience and the pilgrim aspect of the play.

11 The simultaneity is stressed in the rubrics by the recurrence of the word "meanwhile, interim" and "then, tunc," which is also a common first word of the rubrics in these plays. The simultaneity was, thus, the main principle of staging the individual scenes of the play (BEVINGTON 1985: 72-73).

12 "The Magi, meanwhile, who first meet one another in the eastern part of the church, 'before the altar' (ante altare), soon proceed on a journey from east to west, following the star to the entrance of the choir (ad ostium chori)" (BEVINGTON 1985: 70).

13 The relevant rubric reads: "and let them [the shepherds] thus proceed to the manger, which will have been readied at the doors of the church (et sic procedant [shepherds] usque ad Presepe, quod ad ianuas monasterii paratum erit)" (OGDEN 2002: 77). As Ogden points out, the phrase "ad ianuas monasterii" might refer specifically to Fleury: either to an entrance on the south side of the nave, the cloister lying south of the church, or to the entrance at the west end of the nave. Considering the external evidence and requirements of the performance, the second option seems to represent the actual position of the Manger. "The term monasterium appears frequently in other texts referring not to the monastery buildings but to the body of the church as distinct from the choir; and more specifically to the nave." (OGDEN 2002: 78) 
From the architectonic point of view (as well as for the mentioned "scenography idea"), the west-work tower of the church (built in around 1067), which is important for the opening "Christmas scene" of the play, ${ }^{14}$ represents a particular point of interest. The likelihood of the Manger being located at this spot springs from the position, usage and symbolic meaning of the tower. This westwork, or the "porch-tower", of Saint-Benoît church with its semi-open structure and location at the west end of the nave corresponds to what Richard Krautheimer defines as narthex: "[...] the transverse vestibule of a church either preceding nave and aisles as an inner narthex (esonarthex) or preceding the facade as an outer narthex (exonarthex); the exonarthex may also serve as the terminating transverse portico of a quadriporticus" (KRAUTHEIMER in SPATZ 2001: 333).

As Nancy Spatz explains in her study Church Porches and the Liturgy in Twelfth-Century Rome, in the $12^{\text {th }}$ century an enthusiasm for remodeling churches and basilicas arose in Rome and one of its impacts was the addition of front porches to churches (SPATZ 2001: 328). Even though the author is interested in the church porches in Rome, she, in general, concludes that: "[...] porches can be explained as 'triumphal openings,' the product of the ideological building campaign of the papacy displaying its triumph over the emperors. According to other scholars, they are part of a classicizing trend inspired by the early Christian forms seen in the basilicas of St. Peter and St. Paul and echoed in Montecassino" (SPATZ 2001: 336).

From the present point of view, a similar situation can be perceived in the case of Saint-Benoît church where the porch-tower represents a massive construction currently open on three sides on the ground floor. Yet, it has not always been like this: Berland (1986: 134) explains that the tower of Saint-Benoît church was not built for the present church, but for an enigmatic project which has never been realized. The ground floor, as well as the first floor, is structured into three long bays on each side and on both levels and an impressive number of sculpted column capitals could be found on both levels. The whole church is decorated with more than 600 sculpted capitals, distributed in the discussed porch-tower (76 pieces), the crypt, the choir, the transept, and the central bell tower (VERGNOLLE 1975).

Back to the play, it should be noted that the dramatic action is initiated by an angel located in a high place (perhaps somewhere over the crossing of the nave and the choir) who announces the Nativity to a group of shepherds. They are frightened at first, then rise and proceed to the Manger, where the midwives ask "Quem queritis?" and the shepherds prostrate in worship. Then they invite the members of the congregation standing nearby to do the same - to worship the Christ Child - which is the moment of the first strong engagement of the present congregation in the dramatic action (CAMPBELL 1985: 86-87).

14 The church of Saint-Benoît-sur-Loire represents the typical three naved basilica with the wreath of chapels around the main altar on the east side where is also situated the crypt beneath the floor of the choir. The present shell of the church was built in several stages over the $11^{\text {th }}$ and $12^{\text {th }}$ centuries: reconstruction works of its famous west tower and porch began in 1067, the east choir and transept were finished in 1108, and the nave was dedicated in 1218 . 
As Ogden (2002: 78) explains, the main public entrance to the church for dignitaries and townspeople was located in the north side of the church, while the doors at the western end led from the porch of the western tower directly into the nave. The ground level of this porch-tower is supported by several unenclosed pillars, representing a convenient open assembly for processions that could enter the nave of the abbey. Moreover, the porch-tower in Fleury was strongly associated with pilgrimage: Pilgrims were fed by the monastery in this ground-level area and were lodged in the second story, from which they could witness services (OGDEN 2002: 78). Therefore, to locate the Bethlehem and the Manger at the door associated with the tower, where wanderers were given food and shelter, seems particularly appropriate.

In the introduction, the rememorative function of the liturgy is mentioned, of which liturgical drama (inseparable from the liturgy in its early form, such as the Ordo Stellae from Fleury) is one of the aptest and most illustrative examples. Lay people come to the church seeking the Lord similarly as Magi came to the Bethlehem seeking the new-born Messiah. The faithful and the Magi witness His birth together and worship this event together in the symbolic space associated with deeds of the true Christian faith (sharing food with those in need, etc.). In this sense, it is possible to agree with Nancy Spatz who claims that Christianity has always been connected intimately with architecture: "During the liturgical year these places and events are memorialized in Christian churches throughout the world. Through liturgy, the church building itself could become a physical metaphor of Solomon's Temple in Jerusalem or of the Heavenly Jerusalem of the Apocalypse" (SPATZ 2001: 327).

In the next scene of the play, the Magi lead by the star come to the Manger and the midwives show them the Child. The former "respond" by offering the gifts, and then decide to sleep there. While they repose, an angel appears above (possibly from one of the openings in the western tower) and warns them to return home by another way. ${ }^{15}$ The Magi follow the instructions so that Herod does not see them, probably moving along one of the side aisles, and enter the choir. There, the cantor begins singing the Te Deum, which marks the end of the play and the beginning of the mass.

As is apparent from the given description, the extensive use of the nave provides the congregation with a significant role in the whole production. David Bevington (1985: 70) suggests that the journeys of Magi and of the shepherds can be seen as metaphorical journeys of faith through which those who are present affirm their commitment to the new-born Christ child. As an example, the author mentions the scene representing a journey that actually takes place in the midst of the witnessing congregation: the shepherd's arrival at the Manger. The shepherds, according to the rubric, "invite the people standing around' them (populum circumstantem) to adore the Christ child" (BEVINGTON 1985: 70). Bevington understands this as a clever strategy, the aim of which is to stress the specific role ordinary people have in the History of Salvation: "The spatial closeness of the congregation to this acting station 
emphasizes the role of the ordinary people, at the same time of Christ's historical birth and at the present moment, in witnessing Christ's Resurrection"16 (BEVINGTON 1985: 70).

\section{Audience aspect and the journeys}

I have earlier mentioned the specific role of the pilgrims' "centre" in Saint-Benoît church, the porch-tower, and the pilgrims as such. Moreover, the pilgrims were not just present in the church during the performances of the play. They actually had just reached the church after many miles of walking and were ready to set on the journey soon again, to walk another thousand miles. This was especially in case of those who did not come only to see the relics of St. Benedict in Fleury, but continued to Santiago de Compostella, the final point of the pilgrim path the monastery is located at. It is, in my opinion, the reason why the phenomenon of the journey, already present in the play, is further emphasized in the way in which the dramatic action communicates with the particular environment of the church.

The pattern of journeys to and from the particular locations is cleverly fabricated in the Ordo Stelleae play: almost every move of the characters being dramatically motivated. Furthermore, the pattern of journeys is matched by a sequence of overlapping scenes, wherein, for instance, the shepherds gather at the Manger while in the east choir the Magi begin their approach toward each other. This moment, as well as the other, is crucial for the association of the Magi with pilgrims: all their activities in the play are, in fact, framed and structured by the movement, making the analogy very clear.

David Bevington states that the Magi, appearing firstly "in procession 'each from his own corner as if from his own land' - that is, from various parts of the church - gather in front of the altar and then proceed following the star to the choir entrance and thence into the nave [...]" (BEVINGTON 1985: 72). The parallel between this procession and that of the shepherds is, according to Bevington, unmistakable: "[...] in both the congregation is invited to see the procession as expressive of its own search for the newborn Christ" (BEVINGTON 1985: 72). There are other examples of processional movements in the play; in fact, there are so many, that is possible to claim: "The play is almost a continuous journey in which processional movement takes on the symbolic significance of discovery or revelation" (BEVINGTON 1985: 72).

The journey-aspect is also relevant for the discussed porch-tower and its function as one of the locations of dramatic action in the production of the play. And not only because, as has already been remarked, the tower was strongly associated with the pilgrims; according to the monastic set of rules called "Consuetudines" from the $13^{\text {th }}$ century, there was a monumental gate in the tower through which liturgical processions emerged (BERLAND 1986: 140). The procession is, to a certain extent, akin to a much longer religious journey, the pilgrimage. Though ordinary liturgical processions covered

16 Ogden also marks that there could have been two stars, as some scholars suggested earlier, for the performance at Rouen. 
only a comparatively small perimeter of the actual monastery, their sacred goal and the means by which it was achieved - the steady walking of a group of people, a communitas that shared the same values and objectives - resembled to some extent those of the pilgrims who set off on much longer journeys to some of the other European pilgrim sites or even to Jerusalem. The open ground floor of the tower, thus, reflected by various means the prolific medieval concept of this sacred journey.

\section{Column capitals}

It seems evident that the porch-tower in any medieval church in general and the one in Saint-Benoit in particular, represented an important place for various liturgical activities. Concerning this tower as one of the possible locations for staging the play, one needs to also take into consideration its sculpted columns. A number of them bears representations of events from the History of Salvation, which gives them a narrative potential, while the others are abstract and purely decorative. ${ }^{17}$

The eminent researcher of the church of Saint-Benoît-sur-Loire, J. M. Berland, states in the study of 1986 that all the columns from the ground-floor (54 units) as well as from the upper floor (80 units) were crowned with sculpted capitals ${ }^{18}$ (BERLAND 1986: 149-150). As the upper floor was closed for most of the medieval period and it does not seem to have been important for staging the play (except the deduction that the station of the angel was situated there), I focus here mainly on the ground level of the tower.

As it has been said before, the scenes which were probably staged nearby the porchtower dealt with the events that took place in Bethlehem. If we admit that the open space of the tower's ground level also played its part in the production - housing the opening or closing procession, for instance - the narrative columns seem highly appropriate in equipping the area. Let us briefly take a look at one of them: in the middle of the middle bay on the northern side of the tower, there is a representation of a woman on a horse holding a baby. This central figure is surrounded by soldiers on both sides of the column. Above the woman, one can notice a depiction of the star. It is a representation of the journey from Bethlehem, the Biblical event that followed the birth of Christ, the star referring to the Magi and their journey to new-born Christ. The motive of the journey is evident in the figure depicted as if in motion and the star, which resembles the movement of the Magi to the Child. Encountering the journey-related decoration

17 For example, there is a small figure in bust (on the capital No. 26) which emerges from an acanthus collar, raising his mask, like an actor from the comedy by Terence. This allusion is appropriate because a manuscript containing a comedy by Terence was actually found in Fleury, now being preserved in Paris (BN lat. 7900) (BERLAND 1986: 151).

18 “Toutes les colonnes engagées des piliers du rez-de-chaussée et de l'étage ont donc été couronnées d'un chapiteau sculpté, ce qui porte le nombre de ces chapiteaux à 54 au rez-de-chaussée et 80 à l'étage, soit un total de 134 chapiteaux. Parmi cet ensemble, il convient d'enlever ceux qui ont été supprimés ou refaits au cours de l'histoire de cette tour. Aussi bien au rez-de-chaussée qu'à l'étage, soit 32 unités." (BERLAND 1986: 149-150) 
in a space located on the route of the regular liturgical procession and probably used as one of the stations of liturgical play endowed with the motif of the journey, indicates elaborate and multifaceted dialogue between the artistic representations and liturgical performance.

This is, however, just one example of many; decoration of many other columns in the porch tower fits well into the plotlines of the Fleury Playbook dramas, while there are also many others which have clearly nothing to do with those texts. The same can be said about the whole space of the church where many sculpted capitals with representations of historical themes can be found. For example, the "false" triforium hosts another collection of sculpted capitals with themes from the Old and New Testament, liturgical drama (column No. 24, The Visit of Sepulchre - Quem Querites tropus), secular theatre (columns 7, 14 and 28) or from the national and local history (BERLAND 1980: 49-54).

Theatrical productions seem to have been immensely popular in Fleury, not only in its liturgical forms but also in the secular ones. This is testified not only by the fact that the manuscripts such as the one containing a comedy by Terence (BN lat. 7900) are preserved in the local library, but also on the basis of the mentioned capitals number 7, 14 and 28 representing scenes from secular theatre, e.g. donkey playing the harp, the exhibitor of an elephant, the bear tamer and others. Berland (1980) explains that these figures were the main characters of the popular theatre of the $12^{\text {th }}$ century and their depiction on the columns bears a witness of the historical presence of the popular theatre in the Loire Valley where the "'jucalatores', 'citharistae' or 'musici' were an integral part of the society"19 (BERLAND 1980: 50).

Berland also mentions that the church buildings with ambulatory that can be found nearby the Loire valley often include three floors in elevation: large arcades, blind arcades and high windows - which is the case of Saint-Benoit-sur-Loire too. Berland explains that this desire of medieval engineers to illuminate the vault was undoubtedly motivated by the presence of frescoes or murals on the cradle-vault (voûte en berceau) of the right part of the choir, or on the sphere vault of the apse ${ }^{20}$ (BERLAND 1980: 42). When thinking about staging liturgical drama in the medieval church, it is, therefore, necessary to consider also other elements of church decoration, which, despite the fact they are usually not preserved, could be also part of the visual setting for the production of the liturgical drama.

19 "Ces deux témoins sont précieux pour l'histoire du théâtre populaire dans le Val de Loire. Les 'jucalatores' ou 'citharistae' 'musici' faisant partie intégrante de la société." (BERLAND 1980: 50)

20 "Les édifices à déambulatoire de la Loire moyenne comportent en élévation trois étages : grandes arcades, arcature aveugle et fenêtres hautes. Ce désir d'éclairer la voûte, presque absent en Poitou, était sans doute motivé par la présence de fresques ou de peintures murales sur le berceau de la partie droite du chœur ou sur le cul de four de l'abside." (BERLAND 1980: 42) 


\section{Conclusion}

To conclude, there is not much new facts to be said for sure about the introduced topic. While studying the Middle Ages, everything that we know for sure is very often had already been discovered, and it is a rare situation being able to come up with a new evidence. However, having the knowledge about the already discovered facts, one might nevertheless put them in a new context and try to imagine how "it" could work from another perspective. How could, for instance, such a fluid activity as the liturgical drama be performed and interact with the space around? In our case, we have several facts: (1) people tended to understand the Mass as a living dramatic form since at least the $9^{\text {th }}$ century; (2) there are commentaries about the rememorative function of the Mass, which is similar to the rememorative drama (where the elements vary according to the interpreter); (3) there is the Fleury Playbook found nearby the church of Saint-Benoît-sur-Loire; (4) the church itself contains many narrative sculpted elements which are placed in the symbolic parts of the church; (5) those parts are associated with the pilgrimage. Summarizing those facts, one thinks mostly about the visual representations and movement that provokes some kinds of associations. Pilgrimage as a kind of procession could be seen as analogy to the sacral movements during the Mass as well as the phenomenon constructed on the idea of "approaching": approaching via movement, representation, and embodiment.

\section{Bibliography}

BERLAND, Jean-Marie. 1980. Les chapiteaux historiés du faux triforium de l'église abbatiale de Saint-Benoît sur Loire. Les Cahiers de Saint-Michel de Cuxa (1980): 11: 33-66.

BERLAND, Jean-Marie. 1986. La tour-porche de Saint-Benoît-sur-Loire: (Architecture et sculpture) au cours de l'Histoire civile et religieuse. Les Cahiers de Saint-Michel de Cuxa (1986): 17: 133-180.

BEVINGTON, David. 1985. The Staging of Twelfth-Century Liturgical Drama in the Fleury Playbook. In Clifford C. Flanigan, Thomas P. Campbell and Clifford Davidson (edd.) The Fleury Playbook: essays and studies. Kalamazoo, Mich.: Medieval Institute Publications, Western Michigan University, 1985: 60-81.

CAMPBELL, Thomas P. 1985. Augustine's Concept of the Two Cities and the Fleury Playbook. In Clifford C. Flanigan, Thomas P. Campbell and Clifford Davidson (edd.) The Fleury Playbook: essays and studies. Kalamazoo, Mich.: Medieval Institute Publications, Western Michigan University, 1985: 81-100.

FLANIGAN, C. Clifford, Thomas P. CAMPBELL and Clifford DAVIDSON. 1985. The Fleury Playbook: essays and studies. Kalamazoo, Mich.: Medieval Institute Publications, Western Michigan University, 1985.

HARDISON, O. B. 1965. Christian rite and Christian drama in the Middle Ages: essays in the origin and early history of modern drama. Baltimore: Johns Hopkins Univesity Press, 1965. 
HEFFERNAN, Thomas J. and E. Ann MATTER. 2001. The liturgy of the medieval church. Kalamazoo, Mich.: Published for The Consortium for the Teaching of the Middle Ages, by Medieval Institute Publications, Western Michigan University, 2001.

MARTINE, Jullian. 2014. Portail roman et drame sacré. Le portail roman, XIe - XIIe siècles : nouvelles approches, nouvelles perspectives (2014): 231-244.

MÂLE, Emile. 1922. L'Art religieux du XIIe siècle en France: étude sur les origines de l'iconographie du Moyen âge. Paris: Armand Colin, 1922.

MCCALL, Richard D. c2007. Do this: liturgy as performance. Notre Dame, Ind.: University of Notre Dame Press, c2007.

OGDEN, Dunbar H. c2002. The staging of drama in the medieval church. Cranbury, NJ: Associated University Presses, c2002.

PARKER, Elizabeth C. 2001. Architecture as Liturgical Setting. In Thomas J. Heffernan and Ann E. Matter. The liturgy of the medieval church. Kalamazoo, Mich.: Published for The Consortium for the Teaching of the Middle Ages, by Medieval Institute Publications, Western Michigan University, 2001: 273-327.

PETERSEN, Nils Holger. 2003. The representational liturgy of the "Regularis Concordia". In Nigel Hiscock. The white mantle of churches: architecture, liturgy, and art around the millennium. Turnhout, Belgium: Brepols, 2003: 107-117.

SPATZ, Nancy. 2001. Church Porches and the Liturgy in Twelfth-Century Rome. In Thomas J. Heffernan and Ann E. Matter. The liturgy of the medieval church. Kalamazoo, Mich.: Published for The Consortium for the Teaching of the Middle Ages, by Medieval Institute Publications, Western Michigan University, 2001: 327-369.

VERGNOLLE, Éliane. 1975. A propos des chapiteaux de Saint-Benoît-sur-Loire: quelques problèmes du chapiteau corinthien au XIe siècle. Les Cahiers de Saint-Michel de Cuxa (1975): 6: 193-202.

VRŠECKÁ, Kateřina. Rubrics of medieval liturgical drama and modern theories of stage directions. Paper for: 14th Triennial Colloquium of the Société Internationalepour l'étude du Théâtre Médiéval [online]. Poznań, Poland, [accessed on 22nd-27th July 2013]. Available online at http://www.staff.amu.edu.pl/ pber/Vrsecka.pdf. 


\section{Mgr. Amálie Bulandrová}

Katedra divadelních studií

Filozofická fakulta, Masarykova univerzita, Brno

400176@mail.muni.cz

Mgr. Amálie Bulandrová (1992) je absolventkou divadelní vědy (FF MU) a studentkou dějin umění (FF MU). V roce 2017 absolvovala čtyřměsíční výzkumný projekt středověkého umění poutních cest Migrating Art Historians, z nějž vychází poznatky uvedené $v$ této studii. V současné době se zabývá převážně scénografií 20. a 21. století.

Amálie Bulandrová (1992) graduated in Theatre Studies from Masaryk University, Faculty of Arts; she is a student of Art History (FF MU). In 2017, Bulandrová took part in a four-month research project targeted at the phenomenon of pilgrimage, Migrating Art Historians, launched by the Art History Seminar (FF MU). This study is largely based on the said project. Bulandrová currently specializes in the modern stage design of the 20th and 21st century. 